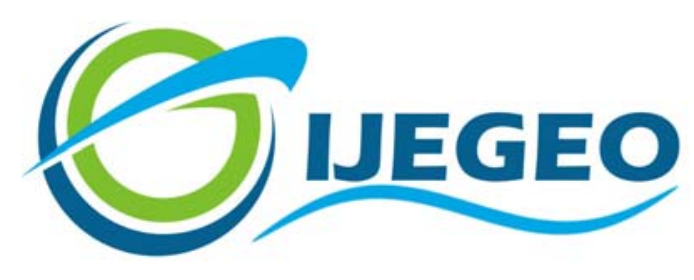

International Journal of Environment and Geoinformatics (IJEGEO) is an international, multidisciplinary, peer reviewed, open access journal.

\title{
GIS-Based Multi-Criteria Decision Analysis of Site Selection for Photovoltaic Power Plants in Çanakkale Province
}

\section{Canan KOCABALDIR, Mehmet Ali YÜCEL}

\author{
Chief in Editor \\ Prof. Dr. Cem Gazioğlu \\ Co-Editors \\ Prof. Dr. Dursun Zafer Şeker, Prof. Dr. Şinasi Kaya, \\ Prof. Dr. Ayşegül Tanık and Assist. Prof. Dr. Volkan Demir
}

Editorial Committee (December 2020)

Assos. Prof. Dr. Abdullah Aksu (TR), Assit. Prof. Dr. Uğur Algancı (TR), Prof. Dr. Bedri Alpar (TR), Prof. Dr. Levent Bat (TR), Prof. Dr. Paul Bates (UK), İrşad Bayırhan (TR), Prof. Dr. Bülent Bayram (TR), Prof. Dr. Luis M. Botana (ES), Prof. Dr. Nuray Çağlar (TR), Prof. Dr. Sukanta Dash (IN), Dr. Soofia T. Elias (UK), Prof. Dr. A. Evren Erginal (TR), Assoc. Prof. Dr. Cüneyt Erenoğlu (TR), Dr. Dieter Fritsch (DE), Prof. Dr. Çiğdem Göksel (TR), Prof.Dr. Lena Halounova (CZ), Prof. Dr. Manik Kalubarme (IN), Dr. Hakan Kaya (TR), Assist. Prof. Dr. Serkan Kükrer (TR), Assoc. Prof. Dr. Maged Marghany (MY), Prof. Dr. Michael Meadows (ZA), Prof. Dr. Nebiye Musaoğlu (TR), Prof. Dr. Masafumi Nakagawa (JP), Prof. Dr. Hasan Özdemir (TR), Prof. Dr. Chryssy Potsiou (GR), Prof. Dr. Erol Sarı (TR), Prof. Dr. Maria Paradiso (IT), Prof. Dr. Petros Patias (GR), Prof. Dr. Elif Sertel (TR), Prof. Dr. Nüket Sivri (TR), Prof. Dr. Füsun Balık Şanlı (TR), Prof. Dr. Uğur Şanlı (TR), Duygu Ülker (TR), Prof. Dr. Seyfettin Taş (TR), Assoc. Prof. Dr. Ömer Suat Taşkın (US), Assist. Prof. Dr. Tuba Ünsal (US), Dr. İnese Varna (LV), Dr. Petra Visser (NL), Prof. Dr. Selma Ünlü (TR), Prof. Dr. Murat Yakar (TR), Assit. Prof. Dr. Sibel Zeki (TR)

Abstracting and Indexing: TR DIZIN, DOAJ, Index Copernicus, OAJI, Scientific Indexing Services, International Scientific Indexing, Journal Factor, Google Scholar, Ulrich's Periodicals Directory, WorldCat, DRJ, ResearchBib, SOBIAD 


\title{
Review Article
}

\section{GIS-Based Multi-Criteria Decision Analysis of Site Selection for Photovoltaic Power Plants in Çanakkale Province}

\author{
Canan Kocabaldır $^{1, *}$ (D), Mehmet Ali Yücel ${ }^{2}$ (D) \\ ${ }^{1}$ Çanakkale Onsekiz Mart University, Graduate School of Natural and Applied Sciences, Department of Geographic Information Technologies, \\ Canakkale, Turkey \\ ${ }^{2}$ Çanakkale Onsekiz Mart University, Faculty of Engineering, Department of Geomatics, Çanakkale, Turkey
}

E-mail: canankocabaldir@gmail.com

Received 15 Fenb 2020 Accepted 26 Sept. 2020

How to cite: Kocabaldır and Yücel (2020). GIS-Based Multi-Criteria Decision Analysis of Site Selection for Photovoltaic Power Plants in Çanakkale Province, International Journal of Environment and Geoinformatics (IJEGEO), 7(3): 347-355. DOI: 10.30897/ijegeo.689570

\begin{abstract}
Energy demand is gradually increasing due to rapid population growth. Using fossil fuels for energy production destroys the environment and fossil energy-based reserves are expected to be depleted in the future. Renewable energy sources are needed to minimize environmental impacts. Solar energy is among the most researched and invested renewable energy sources. There is diversity in renewable energy sources in Çanakkale province but it is not sufficient when the potential is considered. Other renewable power plants except the wind should also be increased among the newly planned plants. Carrying out a comprehensive solar power plant analysis is the first step to provide a cost-effective and well-performing project, and so choosing a suitable location is a critical point towards developing solar energy projects. Knowing potential sites is a fundamental point for annual power plant production forecasting and financial feasibility. With the integration of Geographic Information Systems (GIS) and Multi-Criteria Decision Analysis (MCDA); a more reliable analysis is carried out, the most suitable places can be determined by considering various criteria. Within this study, using spatial analysis, it is aimed to determine areas where photovoltaic (PV) solar power plant can be established in Çanakkale province by GIS-MCDA and how much of energy demand can be supplied in case of installation. Criteria and restriction factors to be used were determined by scanning the literature in detail as part of the relevant legal regulations. According to the restriction map generated, $96 \%$ of Çanakkale province is restricted site since the restriction factors was considered refinedly. Analytical hierarchy process (AHP) will be used as a method of analysis and after acquiring the optimal sites, the annual electric power generation potential in those sites will be calculated. The outputs of this study will contribute development strategy and national energy planning.
\end{abstract}

Keywords: Multi-Criteria Decision Analysis, Analytical Hierarchy Process, Photovoltaic Power Plants, GIS, Çanakkale

\section{Introduction}

According to the estimates of the World Energy Forum, fossil-energy reserves are expected to be depleted in the next century (Cengiz and Mamiş, 2016). In addition, the use of fossil fuels gives rise to disrupt the balance of the Earth and as a result of this; it causes major problems concerning the present and the future such as environmental pollution and climate change (Ülker et al., 2018; Ahmetoğlu and Tanık, 2020). Therefore, clean energy resources are needed to ensure that energy needs can be met in a sustainable manner and environmental hazards are minimized.

There is diversity in renewable energy sources in the province of Çanakkale, but it is not sufficient considering the potential. In Çanakkale, wind energy takes placed on the top in renewable energy sources and in the current situation, together with wind power plants, fossil fuel plants equilibrates in interconnected system. Production sources are domestic and imported coal in fossil fuels. Among the newly planned power plants, other renewable energy plants other than wind should be increased (Özgören and Koyuncu, 2018).
The integration of GIS with other techniques provides a better view for policymakers to improve their choices and to optimize their options considering various subjective and conflicting criteria. Integration of GIS and MCDA is best suited for solving complex site selection problem and the combination of these two tools provides a more reliable decision for the most suitable site selection (Garni and Awasthi, 2018).

Li (2013) weighted the economic and efficiency higher level criteria and criteria which are subclass of higher level criteria using AHP method. The city of Waterloo in Canada was the study area for macro-scale analysis. Areas where installation is not possible such as water bodies and protected lands were classified into a binary data format with suitable and non-suitable classifications and then they were excluded. Four large potential sites were selected by filtering out small discrete areas. Sensitivity analysis was done by changing weights of important criteria, and sensitivity analysis resultant maps were produced under seven scenarios. The feasibility assessments of the selected sites were performed by visiting the sites in Waterloo and collecting the land 
verification data. Site selection results proved to be realistic.

Uyan (2016) determined the areas where solar power plant can be installed in Çumra district, Konya, Turkey by using GIS and AHP. Class I, II and III agricultural lands, forest lands and environmental protection areas are defined as restricted areas. The most suitable areas are determined with Weighted Overlay tool in ArcGIS.

Noorollahi et al. (2016) determined the areas suitable for solar power plant installation in Iran using GIS and Fuzzy AHP. In this study based on the political divisions of Iran, the results for 1057 regions were investigated and analyzed. Some surveys about the positioning of solar power plants by Delphi method have been prepared and given to four experts (academic, government, industry). Up to 14 criteria were obtained from expert evaluations, but three criteria with the lowest score were removed to avoid further complexity of the study. Experts were asked to do pairwise comparisons with very high, high, medium high, medium, medium low, low, very low linguistic terms and then these terms were converted to triangular fuzzy numbers. The layers associated with the defined constraints were created and combined with AND logic, and so unsuitable regions were mapped to exclude them from the final map. Using super decisions software, weights of criteria were determined with FAHP. Criteria layers were overlapped by SAW (Simple Additive Weight) method and land suitability map was obtained.

Yousefi et al. (2018) selected a solar power plant location in Markazi, Iran using a GIS-based Boolean and Fuzzy Logic Model. Restrictions were excluded with the Boolean model. The excluded areas were assigned a value of 0 , suitable areas were assigned to a value of 1 and binary maps were generated. All restriction layers were combined with the AND operator. In Fuzzy Logic, various fuzzy membership functions are applied to blur map pixels. Maps were combined using fuzzy operators. Since it is not necessary to combine all layers with a single operator; fuzzy inference network with OR, Gamma and SUM operators were used. The result map was obtained by combining the Fuzzy and Boolean maps.

Tahri et al. (2015) conducted a site selection study in Varzazat, Morocco. AHP was used as the analysis method. The four criteria as climate, orography, land use and location; seven factors as land use, slope, aspect, solar radiation, distance to roads, distance to urban area and land surface temperature which are subclass of criteria were used in the study. In the land use criteria, NDVI formula was applied to LANDSAT OLI 8 satellite data to determine whether the areas are agricultural or not. However vegetation indices and waterway maps were expressed in binary classification. Land surface temperatures were obtained from LANDSAT OLI 8 thermal band by converting pixel values into spectral radiance and converting spectral radiance into temperature in Kelvin and degree Celsius using ERDAS Imagine software.
Georgiou and Skarlatos (2016) conducted their study in Limassol, Cyprus. They used a threshold of 0.45 in the NDVI index to exclude high vegetation areas and excluded surface waters and residential areas using modified normalized difference water index (MNDWI) and normalized difference building index (NDBI). Against the subjectivity of expert decisions, sensitivity analysis was conducted under different scenarios in which weights obtained from experts were changed and equal weighting of all criteria is examined.

Suh and Brownson (2016) conducted their study in Ulleung Island, Korea and used the Fuzzy AHP method. They modified the solar radiation values of the output of the ArcGIS solar radiation tool using their correlation with data observed by meteorological administration in 2010, and decreased the uncertainty of the atmospheric transmissivity parameter input in tool. They modified the tool output duration of sunshine values using a regression equation between the output and data of average sunshine hours observed for the past 20 years from meteorological administration.

Garni and Awasthi (2017) conducted their study in Saudi Arabia. They used the tension type spline method in ArcGIS to interpolate the annual average temperature for the entire study area. They overlapped the criterion maps with Weighted Sum Overlay using the weights obtained from AHP and then developed a land suitability index (LSI) to visualize the spatial distribution of potential areas on the suitability map. Sensitivity analysis was performed.

Doljak and Stanojevic (2017) conducted their study in Serbia. They interpolated data about annual average duration of sunshine, relative humidity and air temperature collected from 56 stations in Serbia for the period 1961-2010 by using Regression Kriging in SAGA GIS software with EU-DEM, geographic latitude and longitude as predictors. NDVI was taken as the criterion and lower scores were given to values close to 1 , which showed the highest density of green leaves. Weighted coefficients for the criteria (climate, orography, vegetation) and factors (solar irradiation, duration of sunshine and so on) obtained by AHP were used as multipliers in the spatial suitability index (SSI) indicating the importance of each criterion and factor, and SSI map was obtained for the territory of Serbia. Subsequently, annual electric energy generation potential and monthly module temperatures to determine energy yield variability during the year were calculated at the places with the highest SSI values.

\section{Methods in solar site selection}

It is useful to list the applied techniques in other studies in order to determine a methodology for site selection studies. Appendix A. shows the applied techniques in other solar PV power plant site selection studies. As seen in it, AHP is the most preferred technique. The reason for this, calculating using the AHP technique is easier than using other techniques. In this technique, pairwise comparisons of criteria is done by assigning scores from 
1 to 9 , criteria weights are found and consistency check is performed. Determination of weights using this technique gives very healthy results. Fuzzy AHP is another technique which alleviates the difficulty in decision-making in classical AHP. TOPSIS is easy to implement, has fewer questions to consider compared to AHP and does not pairwise comparisons and consistency check (Kahraman et al., 2006). ELECTRE has a complex calculation procedure. WLC is a combination rule to overlay the criteria map layers and was implemented in ArcGIS as the Weighted Overlay tool, it can be found in the Overlay toolset belonging to the Spatial Analyst toolbox (Nyerges and Jankowski, 2009).

SAW is the simplest way for aggregating the used criteria in order to compute a suitability index (SI) for each cell in the study area (Georgiou and Skarlatos, 2016).

\section{Decision criteria and restriction factors}

It is useful to list the criteria and restriction factors used in other studies in order to decide the criteria and restriction factors to be used. Appendix B. shows the criteria used in other solar PV power plant site selection studies and Appendix C. shows the restriction factors to be used in other solar PV power plant site selection studies.

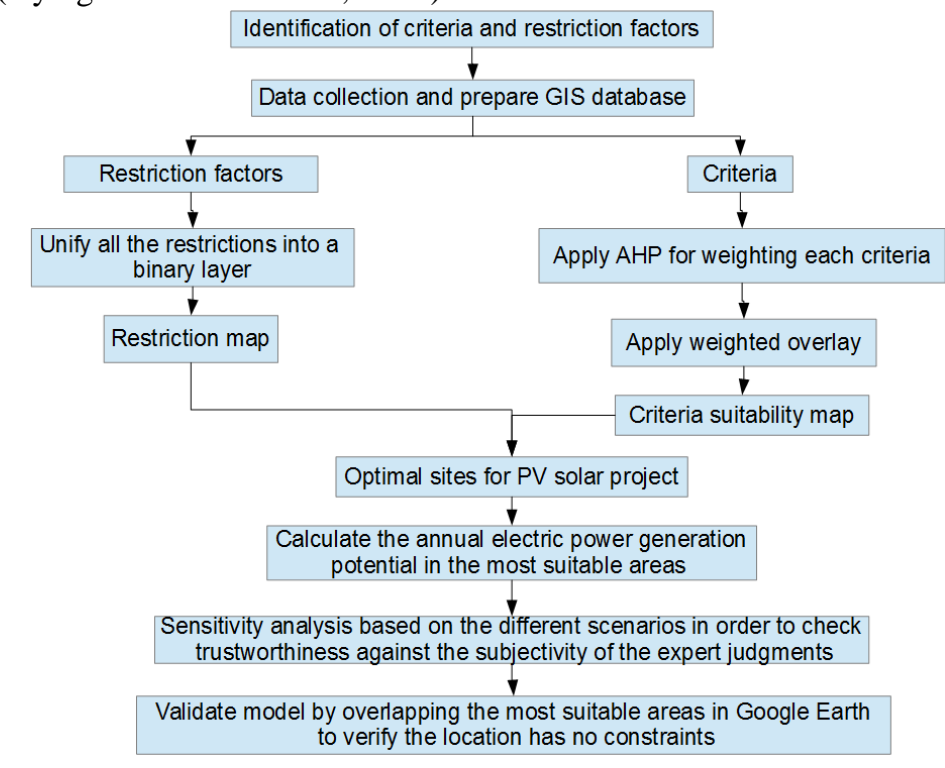

Figure 1. Flow chart of the proposed methodology.

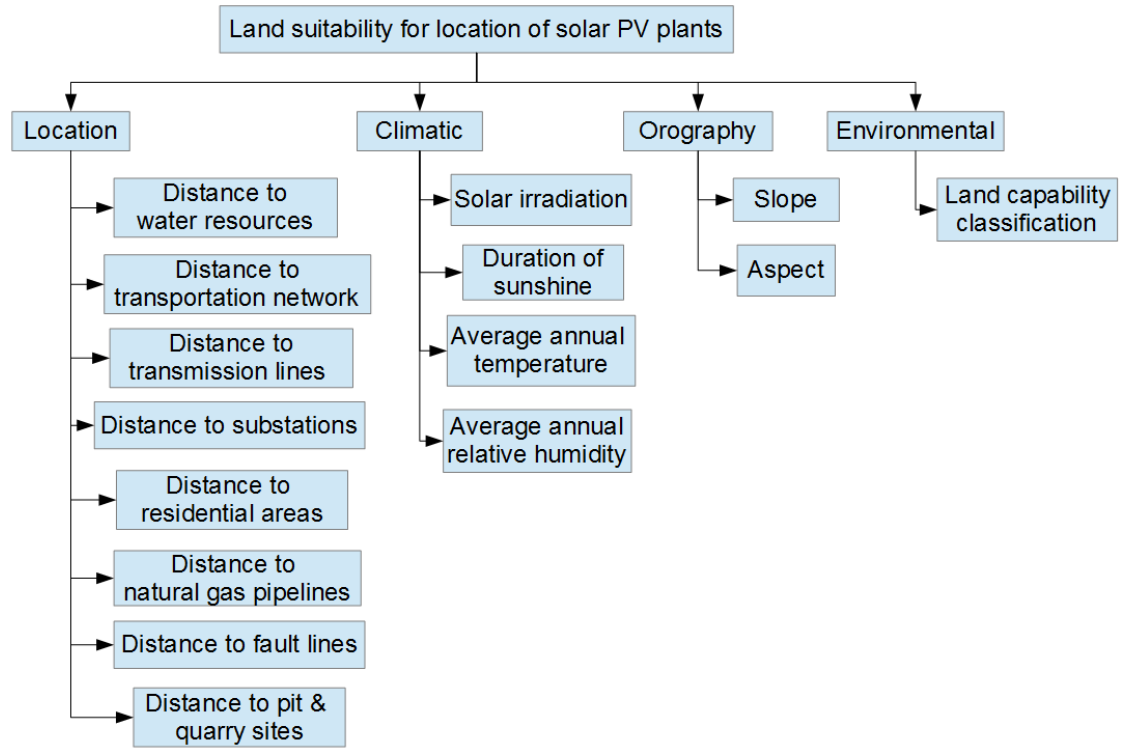

Figure 2. Hierarchy of higher level criteria and criteria

\section{Materials and Methods}

After determining the criteria and restriction factors to be used, the steps below, which are also included in the Figure 1 showing the flow chart of methodology for this study, are followed:
- In the first stage, restrictions are classified into a binary data format with suitable and unsuitable classifications to exclude unsuitable sites.

- In the second stage, AHP technique is applied to determine the weight of each criterion.

- In the third stage, weighted overlay tool in ArcGIS software is used in order to overlay all criteria maps 
with consideration of their weights obtained from AHP.

- In the fourth stage, restricted sites are excluded from potential areas for the solar PV site selection.

- In the fifth stage, the annual electric power generation potential is calculated for the most suitable areas. How much of energy demand can be supplied in case of installation is determined.

- In the sixth stage, sensitivity analysis based on the different scenarios is done.

- In the seventh stage, the model is validated by overlapping the most suitable areas in Google Earth.

\section{Identification of criteria}

The criteria to be used were chosen considering the frequency of use of the criteria in the previous studies. Figure 2 shows the higher level criteria and criteria which are subclass of higher level criteria to be used in this study. The classification of the criteria under higher level criteria has reduced the number of paired comparisons from 105 to 41 for 15 criteria since only the subclasses of the same higher level criteria will be made pairwise comparison.

Solar irradiation: This criterion is the most important since it defines the potential electricity power generation directly. Solar irradiation and duration of sunshine maps can be produced using Solar Radiation tool in ArcGIS software. This tool allows to map the solar radiation in the geographical area for a specific period of time using digital elevation model (DEM) and considers changes in the azimuth and position of the sun, as well as the effects of surface objects or topography-dependent shading on the input DEM (Carl, 2014; Öztürk and Serkentiz, 2018).

Duration of sunshine: The duration of sunshine is an important criteria because solar energy is an intermittent source. If the sun does not shine, there will be no energy production (Doljak and Stanojevic, 2017; Gazioğlu et al., 2014). Higher amounts of duration of sunshine is desirable for this criterion.

Average annual temperature: It is stated in the literature that increasing the ambient air temperature decreases panel efficiency. Studies have shown that the amount of generated energy declines by about $0.4 \%-0.5 \%$ for every $1^{\circ} \mathrm{C}$ rise in the cell temperature at temperatures above 25 ${ }^{\circ} \mathrm{C}$ (Noorollahi et al., 2016). Therefore, areas with high temperatures are not suitable.

Average annual relative humidity: This criterion affects the radiation level of sunlight and entry into the solar cell housing. Therefore, the increase in humidity is inversely proportional to the efficiency of the solar panels.

Distance to water resources: Due to the flood risk, too close proximity and due to the panel cleaning, too much distance to water resources is not desired.

Distance to transportation network: In this criterion, proximity to roads is required in order to avoid additional costs for building new roads and infrastructures in order to provide transportation for power plant installation.

Distance to transmission lines and substations: When the power plant is close to transmission lines and substations, it helps to minimize the loss of power in the transmission, as well as avoiding the high cost of installing new lines.

Distance to residential areas: Proximity to the consumer is economically beneficial. However, considering future expansions of areas, a certain distance buffer should be established.

Distance to natural gas pipelines and fault lines: Distance to fault lines is a criterion to avoid the negative impact of earthquakes on the power plant and distance to natural gas pipelines is the criterion for avoiding any accidental adverse effects.

Distance to pit \& quarry sites: Proximity to these areas is not desired due to dust emission.

Slope: Flat terrain is desired for solar plants. In most studies, only 3\%-10\% slope degrees have been considered to exclude the very steep areas (Garni and Awasthi, 2018; Gazioğlu et al, 2004). As the slope value of $3 \%$ increases, the cost of investment increases gradually.

Aspect: In this criterion, south-facing lands are preferred and north-facing lands have low suitability.

Land capability classification: In this criterion, panel installation on arable land is restricted. The arability of the soils decrease as the class code increases (Kaya et al., 2002).

\section{Identification of restriction factors}

The selected restriction factors in order to use in this study are; protected lands, water resources, slope, transportation network, residential areas, natural gas pipelines, land use and cover, aspect, pit and quarry sites, fault lines, landslide sites, military zones and land capability classification. The restriction factors to be used was chosen considering the frequency of use of the restriction factors in the previous studies.

\section{Results and Discussion}

Primarily, restriction map was generated using data acquired from public institutions and online resources considering legislative regulations and previous studies. Subsequently, solar irradiation, duration of sunshine, slope and aspect criteria maps were generated for weighted overlay. ArcGIS 10.3 software was used in this study for all spatial analysis operations.

\section{Restriction map}

Restriction map contains protected lands, forest lands and agricultural lands except marginal lands, military and military forbidden zones vectorized from 
environmental plan, pit and quarry sites with a buffer area of 200 meters, lake - dam - streams and shoreline with a buffer area of 100 meters, highways obtained from OSM (OpenStreetMap) with a buffer area of 100 meters, residential - tourism - industrial areas with urban development areas in environmental plan, active faults with a buffer area of 300 meters, north - north east - north west facing areas, I - II - III - IV classes which are arable land of Land Capability Classification, lands with a slope greater than 20\%, short distance preservation area of water resources that provide water intended for human consumption and wetlands with a buffer area of 2500 meters. Consequently, total restricted area percentage is $95 \%$ as 9390 square kilometer in Çanakkale. This high rate which occurs with the sensitive handling of restrictions will minimize the risk of solar project rejection. Figure 3 shows the restriction map produced.

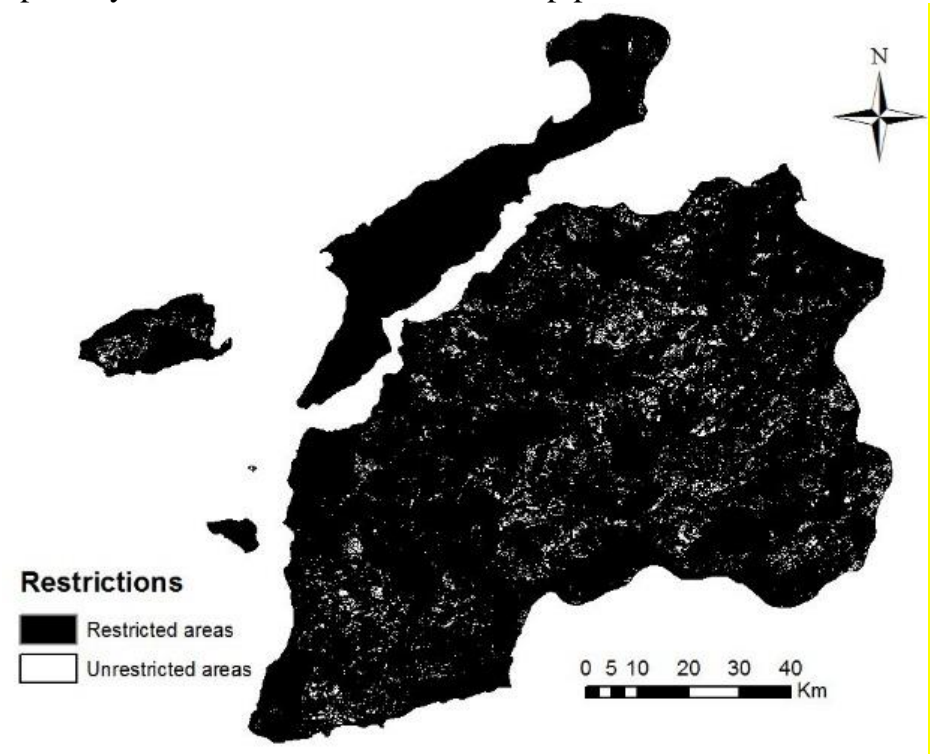

Figure 3. Restriction map of the study.

Table 1. Parameter values used in Area Solar Radiation tool

\begin{tabular}{|c|c|c|c|}
\hline Parameter & Value & Parameter & Value \\
\hline DEM & $30 \mathrm{~m}$ resolution & $\begin{array}{l}\text { Slope and Aspect Input } \\
\text { Type }\end{array}$ & FROM_DEM \\
\hline Latitude & 40.1 & Calculatios Directions & 32 (Default) \\
\hline Sky Size & 512 & Zenith Divisions & 16 \\
\hline Time Configuratic & Multiple Days in a Year (2018) & Azimuth Divisions & 16 \\
\hline Day Interval & 1 & Diffuse Model Type & Standard overcast sky \\
\hline Hour Interval & 1 & Diffuse Proportion & 0.3 (Default) \\
\hline Z Factor & 1 (Default) & Transmissivity & 0.5 (Default) \\
\hline
\end{tabular}

Figure 4. Solar irradiation map to be used in analysis. 


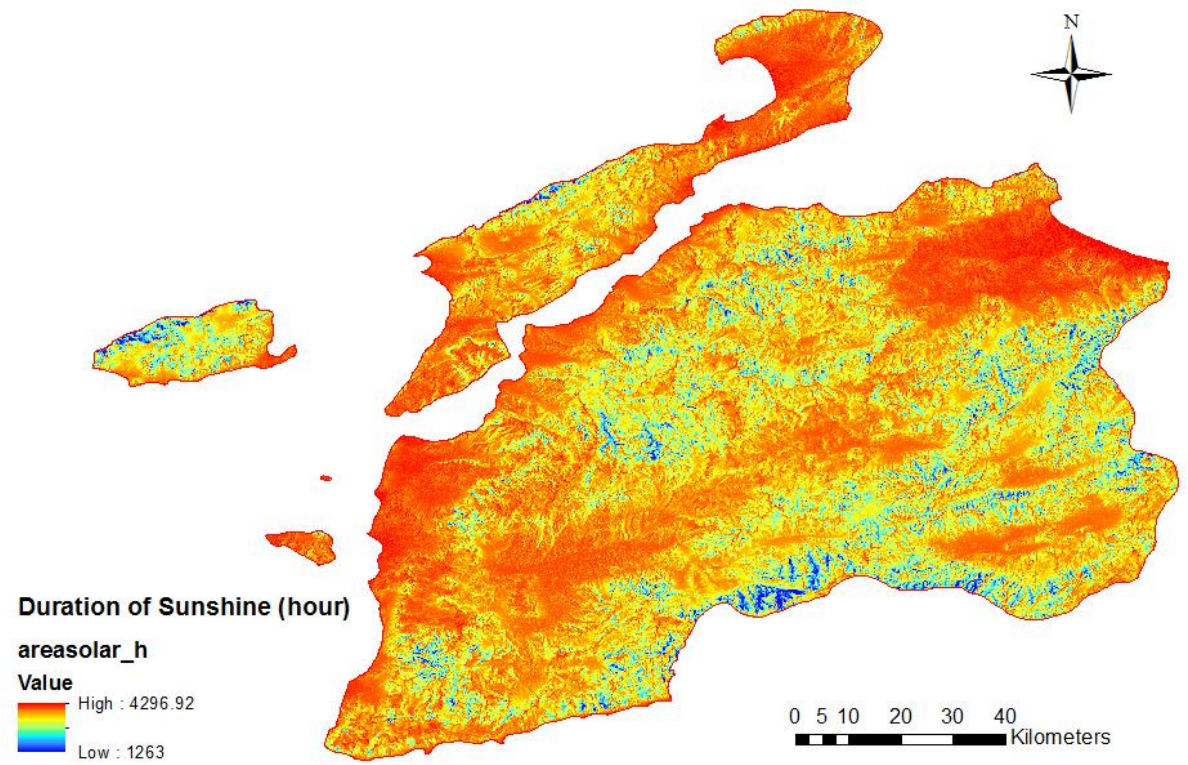

Figure 5. Duration of sunshine map to be used in analysis

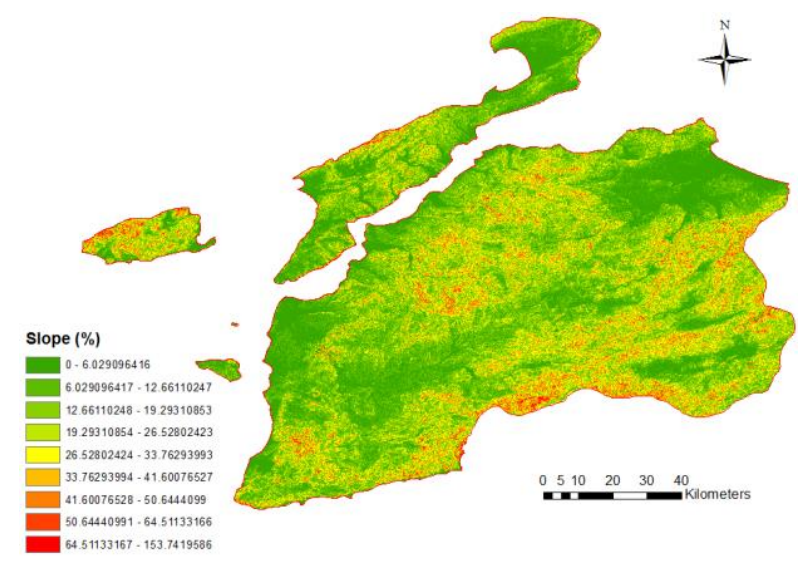

Figure 6. Slope map to be used in analysis.

\section{Solar irradiation and duration of sunshine mapping}

ASTER GDEM v2 with a resolution of $30 \mathrm{~m}$ was used as input DEM to produce these two maps through solar radiation tool in the ArcGIS software. The used input parameters in the tool were determined by the information obtained from other studies. Table 1 shows the parameter values used in tool, Figure 4 shows solar irradiation map produced and Figure 5 shows duration of sunshine map produced.

\section{Slope and aspect mapping}

The same DEM was used as input to produce these two maps. Figure 6 shows slope map and Figure 7 shows aspect map produced.

\section{Conclusions}

This paper presents the findings from a detailed literature review about site selection of PV solar power plants. Firstly, the frequency of use of MCDA techniques,

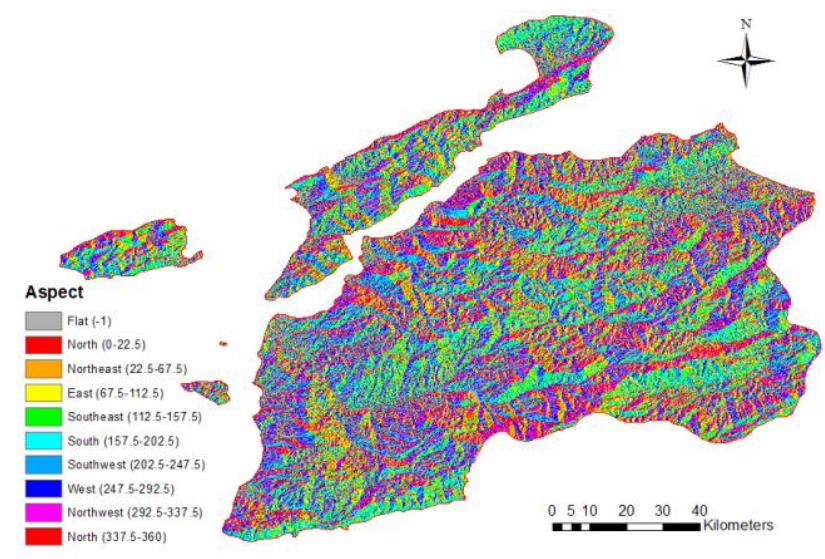

Figure 7. Aspect map to be used in analysis.

criteria and restriction factors used in other studies were determined and so the technique, criteria and restrictions were selected among them easily also taking into account the characteristics of the city. Subsequently, this study focused on the selection of the most suitable locations for photovoltaic solar power plants using spatial analysis and geographic data in different layers. Following the production of the restriction map, MCDA criteria maps and MCDA infrastructure were created. The integration of GIS and MCDA overcomes complex planning problems and gives very dependable results. With this study, the opportunity to invest in the most efficient project has been provided and it is recommended to increase the investments in solar energy in Çanakkale.

\section{Acknowledgements}

The Scientific Research Projects Coordination Unit of Çanakkale Onsekiz Mart University under FYL-20192876 numbered project funded this research. 


\begin{tabular}{|c|c|c|c|c|c|c|c|c|}
\hline Studies & AHP & TOPSIS & $\begin{array}{l}\text { Fuzzy } \\
\text { AHP }\end{array}$ & $\begin{array}{l}\text { ELECTRE- } \\
\text { TRI }\end{array}$ & $\begin{array}{l}\text { Fuzzy } \\
\text { Logic }\end{array}$ & WLC & SAW & Boolean \\
\hline $\operatorname{Li~(2013)~-~[a]~}$ & $\mathrm{X}$ & - & - & - & - & - & - & $\mathrm{X}$ \\
\hline Uyan (2016) - [b] & $\mathrm{X}$ & - & - & - & - & - & - & - \\
\hline Gerçek (2018) - [c] & $\mathrm{X}$ & - & - & - & - & - & - & - \\
\hline Noorollahi et al. (2016) - [d] & - & - & $X$ & - & - & - & - & - \\
\hline Yousefi et al. (2018) - [e] & - & - & - & - & $\mathrm{X}$ & - & - & $\mathrm{X}$ \\
\hline Tahri et al. (2015) - [f] & $\mathrm{X}$ & - & - & - & - & - & - & - \\
\hline Mohammadı, M., Hosseınalı, & - & - & - & - & - & - & - & - \\
\hline Zoghi et al. (2015) - [g] & $\mathrm{X}$ & - & - & - & $\mathrm{X}$ & $\mathrm{X}$ & - & $\mathrm{X}$ \\
\hline Suh-Brownson (2016) - [h] & - & - & $\mathrm{X}$ & - & - & - & - & $\mathrm{X}$ \\
\hline Sanchez-Lozano et al. (2013) - [i] & $\mathrm{X}$ & $\mathrm{X}$ & - & - & - & - & - & - \\
\hline Sanchez-Lozano et al. (2014) - [j] & - & - & - & $\mathrm{X}$ & - & - & - & - \\
\hline Doljak-Stanojevic (2017) - [k] & $\mathrm{X}$ & - & - & - & - & - & - & - \\
\hline Garni-Awasthi (2017) - [1] & $\mathrm{X}$ & - & - & - & - & - & - & - \\
\hline Georgiou-Skarlatos (2016) - [m] & $X$ & - & - & - & - & - & $\mathrm{X}$ & - \\
\hline Effat $(2013)-[n]$ & $X$ & - & - & - & - & - & - & - \\
\hline Vaghela et al (2018) & $\mathrm{X}$ & - & - & - & - & - & $X$ & - \\
\hline
\end{tabular}

Appendix B. Criteria used in previous solar PV power plant site selection studies

\begin{tabular}{|c|c|c|c|c|c|c|c|c|c|c|c|c|c|c|c|}
\hline Criteria & [a ] & {$[\mathrm{b}]$} & {$[\mathrm{c}]$} & [d] & [e ] & [ f ] & {$[\mathrm{g}]$} & {$[\mathrm{h}$ ] } & [ i ] & {$[\mathrm{j}]$} & {$[\mathrm{k}]$} & [1] & {$[\mathrm{m}]$} & {$[\mathrm{n}]$} & Count \\
\hline Slope & $\mathrm{X}$ & $X$ & - & $X$ & $\mathrm{X}$ & $X$ & $X$ & $\mathrm{X}$ & $X$ & $X$ & $\mathrm{X}$ & $\mathrm{X}$ & $\mathrm{X}$ & - & 12 \\
\hline Aspect & $\mathrm{X}$ & - & $\mathrm{X}$ & - & - & $\mathrm{X}$ & $\mathrm{X}$ & - & $\mathrm{X}$ & $\mathrm{X}$ & $\mathrm{X}$ & $\mathrm{X}$ & - & $\mathrm{X}$ & 9 \\
\hline Solar irradiation & $X$ & - & $\mathrm{X}$ & $\mathrm{X}$ & $\mathrm{X}$ & $X$ & $X$ & $\mathrm{X}$ & $X$ & $X$ & $\mathrm{X}$ & $X$ & $\mathrm{X}$ & $\mathrm{X}$ & 13 \\
\hline Distance to water resources & $\mathrm{X}$ & - & $\mathrm{X}$ & - & $\mathrm{X}$ & - & - & - & - & - & - & - & - & - & 3 \\
\hline Distance to transportation network & $\mathrm{X}$ & $X$ & $\mathrm{X}$ & $X$ & $\mathrm{X}$ & $X$ & $X$ & $\mathrm{X}$ & $X$ & $X$ & - & $X$ & $\mathrm{X}$ & $X$ & 13 \\
\hline Distance to transmission lines & $\mathrm{X}$ & $\mathrm{X}$ & $\mathrm{X}$ & $\mathrm{X}$ & - & - & $X$ & $\mathrm{X}$ & $X$ & $\mathrm{X}$ & - & $X$ & $\mathrm{X}$ & $\mathrm{X}$ & 11 \\
\hline Distance to substations & - & $X$ & $\mathrm{X}$ & - & - & - & - & - & $X$ & $X$ & - & - & - & - & 4 \\
\hline Distance to urban areas & - & $\mathrm{X}$ & $\mathrm{X}$ & $\mathrm{X}$ & $\mathrm{X}$ & $\mathrm{X}$ & $\mathrm{X}$ & - & $X$ & $\mathrm{X}$ & - & $\mathrm{X}$ & - & $\mathrm{X}$ & 10 \\
\hline Land use and cover & - & $X$ & - & $X$ & $\mathrm{X}$ & $X$ & - & - & - & - & - & - & $X$ & - & 5 \\
\hline Distance to natural gas pipelines & - & - & $\mathrm{X}$ & - & - & - & - & - & - & - & - & - & - & - & 1 \\
\hline Distance to fault lines & - & - & $\mathrm{X}$ & - & $\mathrm{X}$ & - & - & - & - & - & - & - & - & - & 2 \\
\hline Sand content & $\mathrm{X}$ & - & - & - & - & - & - & - & - & - & - & - & - & - & 1 \\
\hline Distance to pit \& quarry sites & $X$ & - & - & - & - & - & - & - & - & - & - & - & - & - & 1 \\
\hline Average temperature & - & - & - & $\mathrm{X}$ & - & - & - & $\mathrm{X}$ & $X$ & $\mathrm{X}$ & $\mathrm{X}$ & $\mathrm{X}$ & - & - & 6 \\
\hline Elevation & - & - & - & $X$ & $\mathrm{X}$ & - & $X$ & - & - & - & - & - & $X$ & - & 4 \\
\hline Cloudy days & - & - & - & $\mathrm{X}$ & - & - & $\mathrm{X}$ & - & - & - & - & - & - & - & 2 \\
\hline Dusty days & - & - & - & $X$ & - & - & $X$ & - & - & - & - & - & - & - & 2 \\
\hline Humidity & - & - & - & $X$ & - & - & $X$ & - & - & - & $X$ & - & - & - & 3 \\
\hline Land Surface Temperature & - & - & - & - & - & $X$ & - & - & - & - & - & - & - & - & 1 \\
\hline Duration of sunshine & - & - & - & - & - & - & $X$ & $X$ & - & - & $X$ & - & - & - & 3 \\
\hline Rainy and snowy days & - & - & - & - & - & - & $X$ & - & - & - & - & - & - & - & 1 \\
\hline Land capability classification & - & - & - & - & - & - & - & - & $X$ & $X$ & - & - & - & - & 2 \\
\hline Plot areas & - & - & - & - & - & - & - & - & $X$ & $X$ & - & - & - & - & 2 \\
\hline NDVI & - & - & - & - & - & - & - & - & - & - & $X$ & - & - & - & 1 \\
\hline Viewshed from primary roads & - & - & - & - & - & - & - & - & - & - & - & - & $\mathrm{X}$ & - & 1 \\
\hline
\end{tabular}


Appendix C. Restrictions used in previous solar PV power plant site selection studies

\begin{tabular}{|c|c|c|c|c|c|c|c|c|c|c|c|c|c|c|c|}
\hline Restrictions & [a ] & [ b ] & [c ] & [d] & [ e ] & {$[\mathrm{f}]$} & {$[\mathrm{g}]$} & {$[\mathrm{h}]$} & [i ] & {$[\mathrm{j}]$} & {$[\mathrm{k}]$} & {$[1]$} & {$[\mathrm{m}]$} & {$[\mathrm{n}]$} & Count \\
\hline Protected lands & $\mathrm{X}$ & $\mathrm{X}$ & - & $X$ & $\mathrm{X}$ & $X$ & $\mathrm{X}$ & $\mathrm{X}$ & $\mathrm{X}$ & $X$ & $X$ & $X$ & $X$ & - & 12 \\
\hline Water resources & $\mathrm{X}$ & $\mathrm{X}$ & $X$ & $X$ & $X$ & $X$ & $X$ & $X$ & $\mathrm{X}$ & - & - & - & $\mathrm{X}$ & - & 10 \\
\hline Slope & $\mathrm{X}$ & - & $X$ & $X$ & $\mathrm{X}$ & - & - & - & - & - & - & $X$ & - & - & 5 \\
\hline Transportation network & $X$ & $\mathrm{X}$ & $X$ & $\mathrm{X}$ & $X$ & - & $X$ & - & $X$ & $X$ & - & $X$ & $X$ & $\mathrm{X}$ & 11 \\
\hline Residential areas & $\mathrm{X}$ & $\mathrm{X}$ & $X$ & $\mathrm{X}$ & $X$ & $\mathrm{X}$ & $X$ & $\mathrm{X}$ & - & $\mathrm{X}$ & - & $X$ & $\mathrm{X}$ & - & 11 \\
\hline Natural gas pipelines & - & - & $\mathrm{X}$ & - & - & - & - & - & - & - & - & - & - & - & 1 \\
\hline Land use and cover (agricultural and forest lands) & - & $\mathrm{X}$ & - & $\mathrm{X}$ & $\mathrm{X}$ & $X$ & $\mathrm{X}$ & $\mathrm{X}$ & $\mathrm{X}$ & - & $X$ & - & $X$ & $\mathrm{X}$ & 10 \\
\hline Aspect & $\mathrm{X}$ & - & $\mathrm{X}$ & - & - & - & - & - & - & - & - & - & $\mathrm{X}$ & - & 3 \\
\hline Solar irradiation & $\mathrm{X}$ & - & - & $X$ & - & - & - & - & - & - & - & - & - & - & 2 \\
\hline Distance to transmission lines & $\mathrm{X}$ & - & - & $\mathrm{X}$ & - & - & - & - & - & - & - & - & - & - & 2 \\
\hline Distance to pit \& quarry sites & $X$ & - & - & - & - & - & - & - & - & - & - & - & - & - & 1 \\
\hline Sand content & $\mathrm{X}$ & - & - & - & - & - & - & - & - & - & - & - & - & - & 1 \\
\hline Land suitability (not on reserved or in-use areas) & $\mathrm{X}$ & - & - & - & - & - & - & - & - & - & - & - & - & - & 1 \\
\hline Fault lines & - & - & - & $\mathrm{X}$ & $X$ & - & - & - & - & - & - & - & - & - & 2 \\
\hline Elevation & - & - & - & - & $\mathrm{X}$ & - & - & $X$ & - & - & - & - & - & - & 2 \\
\hline Slope failure zones (rock fall) & - & - & - & - & - & - & - & $X$ & - & - & - & - & - & - & 1 \\
\hline Areas of high landscape value & - & - & - & - & - & - & - & $X$ & - & $X$ & - & - & - & - & 2 \\
\hline Military zones & - & - & - & - & - & - & - & - & $X$ & $\mathrm{X}$ & - & - & - & - & 2 \\
\hline Water infrastructure & - & - & - & - & - & $X$ & - & - & $X$ & $\mathrm{X}$ & - & - & - & - & 3 \\
\hline Community interest sites (LICs) & - & - & - & - & - & - & - & - & $X$ & $X$ & - & - & - & - & 2 \\
\hline Land capability classification & - & $X$ & - & - & - & - & - & - & - & - & - & - & - & - & 1 \\
\hline
\end{tabular}

\section{References}

Ahmetoğlu, S., Tanık, A. (2020). Management of Carbon Footprint and Determination of GHG Emission Sources in Construction Sector, International Journal of Environment and Geoinformatics, $\quad$ 191-204. doi.10.30897/ijegeo.726913

Carl, C. (2014). Calculating Solar Photovoltaic Potential on Residential Rooftops in Kailua Kona, Hawaii (Master's thesis). University of Southern California, California, Los Angeles, US.

Cengiz, M.S., Mamiş, M.S. (2016). Thermal solar energy use and efficiency analysis of CSP systems. BEU Journal of Science, 5(1), 1-13, 2016.

Doljak, D., Stanojevic, G. (2017). Evaluation of natural conditions for site selection of ground-mounted photovoltaic power plants in Serbia. Energy 127 (2017) 291-300.

Effat, H.A. (2013). Selection of potential sites for solar energy farms in Ismailia Governorate, Egypt using SRTM and Multicriteria Analysis. Cloud Publ. Int. J. Adv. Remote Sens. GIS 2 (2013) 205-220.

Garni, H.Z., Awasthi, A. (2017). Solar PV power plant site selection using a GIS-AHP based approach with application in Saudi Arabia. Applied Energy (2017),

Garni, H.Z., Awasthi, A. (2018). Chapter 2 - Solar PV Plants Site Selection: A Review. Advances in Renewable Energies and Power Technologies Vol. 1: Solar and Wind Energies (pp. 57-75).

Gazioğlu, C., Aipar, B., Yücel, Z., Müftüoğlu, A., Güneysu, C., Ertek, T., Demir, V., Kaya, H. (2014).
Morphologic Features of Kapıdağ Peninsula and its Coasts (NW-Turkey) using by Remote Sensing and DTM., International Journal of Environment and Geoinformatics, 1(1), 48-63, doi. 10.30897/ijegeo.300739.

Gazioğlu, C., Yücel, Z.Y., Kaya, H., Doğan, E. (2004). Geomorphological features of Mt. Erciyes using by DTM and remote sensing technologies. XXth ISPRS Congress, Istanbul.

Georgiou, A., Skarlatos, D. (2016). Optimal site selection for sitting a solar park using multi-criteria decision analysis and Geographical Information Systems. Geosci. Instrum. Method. Data Syst, 5, 321332, 2016.

Gerçek, Y. (2018). Optimal location analysis of solar energy plants with geographical information systems: Case study of Malatya province, Turkey (Master's thesis). KTÜ, Trabzon, Turkey. doi.org/10.1016/j.apenergy.2017.10.024.

Kahraman, C., Beşkese, A., Bozbura, T.T. (2006). Fuzzy Regression Approaches and Applications, StudFuzz 201, 589-615

Kaya Ş, Musaoğlu N, Göksel Ç, Gazioğlu C. (2002), Examining the land-use classes by means of digital elevation model and remotely sensed data, Observing Our Environment from Space-New Solutions for a New Millennium: Proceedings of the 21st EARSel Symposium, Paris, France, 14-16 May 2001, Vol. 21, 379.

Li, D. (2013). Using GIS and remote sensing techniques for solar panel installation site selection (Master's thesis). University of Waterloo, Canada. 
Mohammad1, M., Hosseinalı, F . (2019). Assessment and Comparison the Location of Six Universities in Tehran City Using GIS and Multi Criteria Decision Making Methods, International Journal of Environment and Geoinformatics, 6(1), 143-147.doi: 10.30897/ijegeo.551753.

Noorollahi, E., Fadai, D., Shirazi, M.A., Ghodsipour, S. (2016). Land suitability analysis for solar farms exploitation using GIS and Fuzzy Analytic Hierarchy Process (FAHP) - a case study of Iran. Energies 2016, 9, 643.

Nyerges, T. L., Jankowski, P. (2009). Making Choices about GIS-Based Multicriteria Evaluation, Regional and urban GIS, 146, The Guilford Press.

Özgören, Y., Koyuncu, S. (2018). Current status and optimization of electrical grids in Çanakkale region for renewable energy systems as future technology. Çanakkale Onsekiz Mart University, Journal of Graduate School of Natural and Applied Sciences, 2018:4,2, 212-236.

Öztürk, B., Serkendiz, H. (2018). Location Selection for Wind Turbines in Balikesir, NW Turkey, Using GIS, International Journal of Environment and Geoinformatics, 5(3), 284-295, doi.10.30897/ijegeo.400025.

Sanchez-Lozano, J.M., Antunes, C.A., Garcia-Cascales, M.S., Dias, C.D. (2014). GIS-based photovoltaic solar farms site selection using ELECTRE-TRI; evaluating the case for Torre Pacheco, Murcia, Southeast of Spain. Renew. Energy 66 (2014) 478494.

Sanchez-Lozano, J.M., Teruel-Solano, J., Soto-Elvira, P.L., Garcia-Cascales, M.S. (2013). Geographical Information Systems (GIS) and Multi-Criteria Decision Making (MCDM) methods for the evaluation of solar farms locations: Case study in south-eastern Spain. Renew. Sustain. Energy Rev. 24 (2013) 544-556.

Suh, J., Brownson, J. R. S. (2016). Solar farm suitability using Geographic Information System fuzzy sets and Analytic Hierarchy Processes: case study of Ulleung Island, Korea, Energies 9 (2016).

Tahri, M., Hakdaoui, M., Maanan, M. (2015). The evaluation of solar farm locations applying Geographic Information System and Multi-Criteria Decision Making methods: case study in southern Morocco, Renew. Sustain. Energy. Rev. 51 (2015) 1354-1362.

Ülker, D., Ergüven, O., Gazioğlu, C. (2018). Socioeconomic impacts in a Changing Climate: Case Study Syria. International Journal of Environment and Geoinformatics, 5(1), 84-93. doi. 10.30897/ijegeo.406273.

Uyan, M. (2016) GIS-Supported mapping of solar power plant sites using AHP method. Pamukkale Univ Muh Bilim Derg, 23(4), 343-351,2017.

Vaghela, B., Parmar, M., Solanki, H., Kansara, B., Prajapati, S., Kalubarme, M. (2018). Multi Criteria Decision Making (MCDM) Approach for Mangrove Health Assessment using Geo-informatics Technology, International Journal of Environment and Geoinformatics, 5(2), 114-131. doi: 10.30897/ijegeo.412511.

Yousefi, H., Hafeznia, H., Yousefi-Sahzabi, A. (2018). Spatial Site Selection for Solar Power Plants Using a GIS-Based Boolean-Fuzzy Logic Model: A Case Study of Markazi Province, Iran. Energies 2018, 11, 1648.

Zoghi, M., Housang Ehsani, A., Sadat, M., Javad Amiri, M. (2015). Optimization solar site selection by Fuzzy Logic Model and Weighted Linear Combination method in arid and semi-arid region: a case study Isfahan-Iran, Renew. Sustain. Energy Rev. 